\title{
Sosyal Güvenlik Sisteminde İş Kazasına Uğrayan Sigortalıya ve Sigortalının Ölümü Halinde Hak Sahiplerine Tanınan Haklar
}

\author{
Rights Granted to an Insured Person Who Has a Work Accident and Rights \\ Owners in the Event of the Death of the Insured in the Social Security System
}

\author{
Atanur Karaahmetoğlu' 1 (1)
}

Öz

Iş kazasına uğrayan sigortalı, bir taraftan bedenen ve ruhen zarar görmekle birlikte, diğer taraftan da maddi zorluklarla karşı karşıya kalmaktadır. Bu nedenle iş kazasına uğrayan sigortalıların hukuki açıdan korunması büyük önem taşımaktadır. Bunun içindir ki, günümüzde her devlet kendi hukuk sistemi içinde iş kazasına uğrayan sigortalılara yönelik birtakım koruyucu adımlar atmıştır. Bu şekilde iş kazasına uğrayan sigortalılara çeşitli haklar tanınmış ve bu hakların sınırları çizilmiştir. Ülkemizde de iş kazasına uğrayan sigortalılara yönelik hukuki bir koruma sağlama düşüncesi 5510 sayılı Sosyal Sigortalar ve Genel Sağlık Sigortası Kanunu'nun yürürlüğe girmesi ile somutlaşmıştr. Ayrıca, 5510 sayılı SSGSSK, iş kazasına uğrayan sigortalılara hukuki bir koruma getirmekle birlikte, iş kazasına uğrayan sigortalılara sağlanan hakların ve sigortalının ölümü halinde de hak sahiplerine tanınan hakların sınırlarını çizmiştir. Bu çalışmada 5510 sayılı Kanunun ilgili maddeleri ve Yargıtay kararları doğrultusunda, iş kazasına uğrayan sigortalının hukuki durumunun ne olduğu, sigortalının ve sigortalının ölümü halinde hak sahiplerinin ne gibi haklarının bulunduğu sorularına bir cevap aranmıştır.

\section{Anahtar Kelimeler}

Sosyal Güvenlik , iş Kazası, Sigortalı, Hak Sahibi, Hak

\begin{abstract}
An insured person who has suffered an occupational accident faces both physical and mental damages and financial difficulties. For this reason, it is of great importance to offer legal protection to insured persons who have suffered work accidents. Therefore, every state has taken some legal steps to protect insured persons who have suffered work accidents, granting various rights to insured persons who were victims of work accidents, and the limits of these rights have been delineated. In Turkey, legal protection for insured persons who have suffered occupational accidents has been achieved with the entry into force of the Social Insurance and General Health Insurance Law No. 5510. In addition, SSGSSK (Law No. 5510) has provided
\end{abstract}

1 Sorumlu Yazar: Atanur Karaahmetoğlu (Arş. Gör.), Kırklareli Üniversitesi, îktisadi ve İdari Bilimler Fakültesi, Çalışma Ekonomisi ve Endüstri ilişkileri Bölümü, Kırklareli, Türkiye. E-posta: atanurkartal@hotmail.com ORCID: https://orcid.org/0000-0001-8306-3178

Attf: Karaahmetoglu, A. (2021). Sosyal Güvenlik Sisteminde İş Kazasına Uğrayan Sigortalıya ve Sigortalının Ölümü Halinde Hak Sahiplerine Tanınan Haklar. Journal of Social Policy Conferences, 81, 213-244. https://doi.org/10.26650/jspc.2021.81.876998 
legal protection to insured persons who have suffered work accidents and has set out the limits of the rights granted to such persons and the rights granted to the rights-holders in case of the death of the insured person. In this study, in line with the relevant articles of Law No. 5510 and decisions of the Supreme Court, a question was asked about the legal status of the insured who suffered an occupational accident: what were the rights of insured persons and of rights-holders in the event of the death of the insured?.

\section{Keywords}

Social Security, Work Accident , Insured, Right Owner, Right 


\section{Extended Summary}

Generally, work accidents are bad events with dire consequences. That is because work accidents happen unexpectedly and insured persons who suffer work accidents are harmed physically and mentally.

The insured person who suffers a work accident experiences physical and mental harm and faces financial difficulties.

In this regard, the insured person who suffers a work accident not only suffers a loss of income but also faces the danger of losing their job. Therefore, the insured person who suffers a work accident needs legal protection.

For this reason, it is very important that the insured person who suffers a work accident is legally protected. In addition, the insured person who suffers a work accident no longer participates in the workforce. Furthermore, the insured person who suffered a work accident may die as a result.

Moreover, in the event of the death of the insured person who suffered a work accident, the spouse, children, and parents of the deceased also experience certain grievances. For this reason, these people are entitled to legal protection.

Social Insurance and General Health Insurance Law No. 5510, grants various rights to the insured person who suffers a work accident. In addition, Law No. 5510 has granted certain rights to rights-holders in the event of the death of the insured person who suffered a work accident.

Article 16 of Law No. 5510 stipulates the rights that rights-holders have in case the insured person dies or survives a work accident.

First of all, the insured person who has suffered a work accident has the right to receive a temporary incapacity benefit during the treatment period. In addition, if the incapacity rate of the insured person who suffered a work accident is over ten percent as determined by a medical board report, the insured person has the right to receive a permanent incapacity benefit.

Second, in the event of the death of the insured person who has suffered a work accident, rights-holders have the right to receive death income, a death pension, a funeral benefit, and a marriage allowance. 
In this context, rights-holders of the deceased insured can receive death income as well as a death pension. While death income is a form of short-term insurance, a death pension is long-term insurance. For this reason, the necessary conditions for granting death income to the rights-holders differ from the necessary conditions for granting the death pension.

Since death income is a payment item made to the beneficiaries within the scope of short-term insurance, there is no requirement that the deceased insured fulfill certain criteria in terms of insurance period or insurance premium in order for the beneficiaries to receive death income. However, since the death pension is covered under death insurance, which is long-term insurance, the deceased insured must fulfill certain conditions in terms of the insurance period and insurance premium.

Law No. 5510 stipulates which principles should be applied in cases in which both death income and death insurance are given to rights-holders. In addition, the conditions under which the rights-holders of the deceased insured person may be entitled to funeral benefits and marriage allowances are specifically regulated.

As a result, rights-holders experience certain grievances in the event of the death of both the insured and the insured as a result of a work accident. For this reason, Law No. 5510 has granted various rights to the insured who have suffered from work accidents. Law No. 5510 also did not ignore the legal status of the rights-holders in the event of the death of the insured who suffered a work accident, granting them various rights. In this way, the law is aimed to alleviate the difficult situation of rights-holders in the event of the death of the insured and the insured who suffered a work accident.

In this study, in line with the relevant articles of Law No. 5510 and Supreme Court decisions, an answer was sought to the questions of the legal status of the insured who suffered a work accident and what rights the rights-holders have in the event of the death of the insured and the insured. In this way, an attempt was made to delineate the limits of the rights granted to the insured and beneficiaries. 


\section{Sosyal Güvenlik Sisteminde İş Kazasına Uğrayan Sigortalıya ve Sigortalının Ölümü Halinde Hak Sahiplerine Tanınan Haklar}

İş kazası nedeniyle sigortalılar genel olarak bedensel ve ruhsal açıdan zarar görmektedir. Zira iş kazasına uğrayan sigortalı ortaya çıkan bedensel zarar nedeniyle sakat kalabilmektedir. Ayrıca, iş kazası nedeniyle bedensel zarar gören sigortalı iş göremez hale de gelmektedir. Bu nedenle iş kazasına uğrayan sigortalı ekonomik açıdan da zarar görmektedir.

İş kazası nedeniyle birçok sigortalı iş göremez hale gelmekle birlikte, birçok sigortalı da hayatını kaybetmektedir. Bu nedenle sigortalının ölümü halinde, sigortalının geride bıraktığı hak sahipleri de birtakım mağduriyetler yaşamaktadır. Dolayısıyla iş kazaları nedeniyle hem sigortalılar, hem de sigortalının ölümü halinde sigortalının geride bıraktığı hak sahipleri birtakım mağduriyetler yaşamaktadır.

Bu çalışmada iş kazasına uğrayan sigortalının ve sigortalının ölümü halinde sigortalının geride bıraktığı kişilerin sahip olduğu hakların neler olduğu konusu ele alınmıştır. Bu amaçla 5510 sayılı Kanunun ne gibi düzenlemeler getirdiği, Yargıtay kararlarında konunun nasıl değerlendirildiği ve öğretinin konuya bakışı üzerinden bir inceleme yapılmıştır.

\section{İş Kazası}

İş kazası, önceden planlanmayan ölümlere, yaralanmalara, makine ve teçhizatın zarara uğramasına veya üretimin bir süre durmasına yol açan olaylardır (Narter, 2017, ss. 10-12). Yaşanan olayın iş kazası olarak kabul edilmesi için, bu olayın ani ve zarar verici mahiyette olması gerekir (Şakar, 2017, s. 197; Sümer, 2020, s. 95). Bu nedenle iş kazası, yıkıcı ve yıpratıcı sonuçlara yol açan vakalardır (Güzel vd., 2020, ss. 394-395). Dolayısıyla aniden ve dışarıdan gelen bir etkenle gerçekleşen olaylar iş kazası olarak kabul edilmektedir (Karakaş, 2019, ss. 444-445).

Genel olarak iş kazası, işverenin otoritesi altındaki işçinin aniden ve diştan gelen bir etken ile meydana gelen olay sonucu bedenen ve ruhen arıaya uğradığ bir durumdur (Demiral, 2017, s. 20-21). Bu nedenle iş kazasına uğrayan işçi, bedenen ya da ruhen zarar görebilmektedir (Günay, 2020, s. 215). Ancak, söz konusu zararın hemen ortaya çıkması şart değildir. Zira Yargıtay olay yaşandıktan belli bir süre sonra da zararın oluşabileceğini, bu nedenle 
olayın etkilerinin zamanla ortaya çıkabileceğini kabul etmiştir (Y.21.HD, T.15.04.2019, E.2018/5018, K.2019/2931).

Meydana gelen iş kazası sonucunda ölüm ve yaralanmalar yaşanmakla birlikte, birtakım maddi kayıplar da yaşanmaktadır (Güneren, 2020, s. 394). Bu nedenle iş kazası yaşanması halinde birçok risk ortaya çıkmaktadır (Emirhan, 2017, s. 16).

$\mathrm{Bu}$ doğrultuda, iş kazası beklenmedik bir anda gerçekleşmektedir ve kaza sonucunda bir zarar ortaya çıkmaktadır (Sümer, 2020, s. 93). Ortaya çıkan zarar bedensel zarar olabileceği gibi ruhi zarar da olabilmektedir (Tuncay ve Ekmekçi, 2017, ss. 381-382).

$\mathrm{Bu}$ açıklamalardan hareketle iş kazası ölüm veya yaralanmalara yol açan, belli bir zararın oluşmasına neden olan olaylardır (Şakar, 2017, ss. 197-198). İş kazası sonucu bir zarar ortaya çıkmaktadır. İş kazası sonucu ortaya çıkan bu zarar, maddi zarar veya manevi zarardır (Günay, 2020, s. 221). Bu nedenle iş kazasının önlenmesi adına gerekli önlemlerin alınması büyük önem taşımaktadır (Narter, 2017, ss. 10-12).

6331 sayılı İş Sağlığı ve Güvenliği Kanunu'nun 3. maddesinin 1-g bendinde bir iş kazası tanımı yapılmıştır. Buna göre, “...Işsyerinde veya işin yürütümü nedeniyle meydana gelen, ölüme sebebiyet veren veya vücut bütünlügünü ruhen ya da bedenen engelli hâle getiren olayı...” şeklinde tanımlanmıştır.

5510 sayılı Sosyal Sigortalar ve Genel Sağlık Sigortası Kanunu'nun 13. maddesinde ise bir iş kazası tanımı yapılmamıştır ve iş kazası olan haller tek tek sayılmıştır.

5510 sayılı Kanunun 13. maddesine göre:

“a. Sigortalının işyerinde bulunduğu sırada,

b. Işveren tarafindan yürütülmekte olan iş nedeniyle sigortalı kendi adına ve hesabına bağımsız çalışıyorsa yürütmekte olduğu iş nedeniyle,

c. Bir işverene bağlı olarak çalışan sigortalının, görevli olarak işyeri dışında başka bir yere gönderilmesi nedeniyle asıl işini yapmaksızın geçen zamanlarda,

d. 5510 sayılı Kanunun 4. maddesinin 1. fikrasının (a) bendi kapsamındaki emziren kadın sigortalının, iş mevzuatı gereğince çocuğuna süt vermek için ayrilan zamanlarda, 
e. Sigortalıların, işverence să̆lanan bir taşıtla işin yapıldı̆̆ yere gidiş gelişi sirasinda, meydana gelen ve sigortaliyı hemen veya sonradan bedenen ya da ruhen engelli hale getiren olaylar" iş kazası olarak düzenlenmiştir.

\section{İş Kazasına Uğrayan Sigortalıya ve Hak Sahiplerine Tanınan Haklar}

İş kazasına uğrayan sigortalı bedensel zarar görmekle birlikte, maddi kayıplar da yaşayabilmektedir (Güzel vd., 2020, s. 402). Buna göre, sigortalı bir gelir kaybına uğramamaktadır. Ayrıca, sigortalının iş kazası nedeniyle malul olması veya ölmesi de mümkündür (Oğuz, 2018, s. 320). Bu nedenle iş kazasına uğrayan sigortalının ve sigortalının ölümü halinde hak sahiplerinin hangi haklara sahip olacağı sorusu akla gelmektedir. 5510 sayılı SSGSSK'nın 31.05.2006 tarihinde kabul edilmesi ile birlikte, iş kazası ve meslek hastalığ1 sigortası ile sigortalıya ve hak sahiplerine sağlanan yardımlar ve bunun için aranan koşullar kısa vadeli sigorta kolları kapsamında düzenlenmiştir. Ancak, 5510 sayılı Kanunda yer alan kısa vadeli sigorta kollarına ilişkin hükümler 01.10.2008 tarihinde yürürlüğe girmiştir. Buna göre iş kazasına uğrayan sigortalının geçici veya sürekli iş göremez duruma gelmesi halinde veya iş kazasına uğrayan sigortalının ölmesi durumunda hak sahiplerine gelir ve aylık bağlanması söz konusudur (Narter, 2015, s. 23). Bu bağlamda gelir ve aylıktan ne anlaşılması geldiğini ele almak isabetli olacaktır.

Gelir, kısa vadeli sigorta kollarından biri olan iş kazası ve meslek hastalığı sigortası kapsamında, sigortalıya, sigortalı öldügü takdirde ise, hak sahiplerine sağlanan sürekli ödemeler iken, aylık uzun vadeli sigorta kolu kapsamında malûllük, vazife malûllüğü yaşlılık ve ölüm sigortası dahilinde yapılan sürekli ödemeler olarak ifade edilmektedir (Elma, 2019, s. 119). 5510 sayılı Kanunun 16. maddesinde iş kazası ve meslek hastalığından sağlanan hakların neler olduğu düzenlenmiştir. Buna göre;

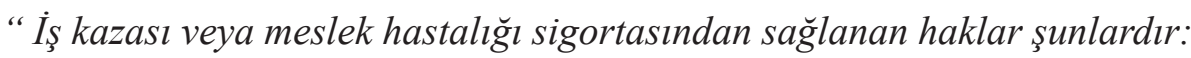

a) Sigortalıya, geçici iş göremezlik süresince günlük geçici iş göremezlik ödeneği verilmesi.

b) Sigortalıya sürekli iş göremezlik geliri bă̆lanması.

c) İş kazası veya meslek hastalı̆̆ı sonucu ölen sigortalının hak sahiplerine, gelir bağlanması. 
d) Gelir bağlanmış olan kız çocuklarına evlenme ödenĕ̆i verilmesi.

e) $\dot{I}_{S ̧}$ kazası ve meslek hastalı̆̆ sonucu ölen sigortalı için cenaze ödeneğ $i$ verilmesi....." şeklinde iş kazası ve meslek hastalığından sağlanan haklar hükme bağlanmıştır.

\section{İş Kazasına Uğrayan Sigortalının Hakları}

İş kazasına uğrayan sigortalı birçok açıdan mağduriyet yaşamaktadır (Güzel vd., 2020, s. 430). Bu nedenle iş kazasına uğrayan sigortalılara çeşitli haklar tanınmıştır (Akdeniz, 2014, s. 10).

$\mathrm{Bu}$ kapsamda iş kazasına uğrayan sigortalı bazı sağlık yardımlarından faydalanabilmektedir (Şakar, 2017, s. 303). Bunun yanında iş kazasına uğrayan sigortalı, bazı parasal yardımlar da alabilmektedir (Mutlay, 2014, s. 254).

\section{İş Kazasına Uğrayan Sigortalıya Yapılan Sağlık Yardımları}

Sağlık yardımları, Genel Sağlık Sigortası kapsamında yapılan yardımlar olmakla birlikte, kısa vadeli sigorta kolu kapsamında yapılan yardımlar arasında yer almamaktadır (Şakar, 2017, s. 203). Zira sağlık yardımları iş kazası ve meslek hastalığı sigorta kolu kapsamında düzenlenmemiştir.

Sağlık yardımları, 5510 sayılı Kanunun 63 vd. maddelerinde düzenlenmiştir. 5510 sayılı Kanunun 63. maddesinde, "Genel sağllk sigortalısinın ve bakmakla yükümlü olduğu kişilerin sağlıklı kalmalarını; hastalanmaları halinde sağlıklarını kazanmalarını; iş kazası ile meslek hastalı̆̆ı, hastalık ve analık sonucu tıbben gerekli görülen sağllk hizmetlerinin karşılanmasını, iş göremezlik hallerinin ortadan kaldırılmasını veya azaltılmasın temin etmek amacıyla Kurumca finansmanı sağlanacak sağlık hizmetleri şunlardır... ”şeklinde sağlık yardımlarının nasıl yapılacă̆ı düzenlenmiştir.

$\mathrm{Bu}$ doğrultuda sağlık yardımlarından ne anlaşılması gerektiğini ele almak isabetli olacaktır. Sağlık yardımları, iş kazasına uğrayan sigortalının sağlığına kavuşması, sigortalının bedeni ve ruhi arızalarının giderilmesi amacıyla yapılan yardımların genel bir görünümüdür (Yavuz, 2015, s. 461). Bu bağlamda iş kazasına uğrayan sigortalıya Genel Sağlık Sigortası kapsamında SGK sağlık hizmet sunucuları tarafından çeşitli yardımlar yapmaktadır (Tuncay ve Ekmekçi, 2017, s. 410; Güzel vd., 2020, s. 426). Buna göre tedavi için gerekli ilaç, araç 
ve gereçler sağlanmakla birlikte, acil sağlık hizmetleri, teşhis ve tedavi hizmetleri sunularak, gerekli durumlarda tedavi için sigortalı başka bir yere de sevk edilebilmektedir (Oğuz, 2018, s. 320). Bu yardımlar sigortalı iyileşene kadar yapılmaktadır. Bu şekilde sigortalının iş göremezlik durumundan çıkması veya sigortalının iş göremezlik oranının azaltılması amaçlanmaktadır (Günay, 2020, ss. 520-521).

Bu açıklamalardan hareketle sağlık yardımları kapsamında sigortalıya sağlık hizmetleri sunulmakla birlikte, sigortalı tedavi edilmekte ve sigortalının yaşamını sürdürebilmesi için gerekli alet, edevat, protez, yürüteç gibi çeşitli ekipmanlar da sigortalıya sağlanmaktadır. Bu kapsamda, iş kazasına uğrayan sigortalı kendisi sağlık harcamaları yaptığ 1 takdirde, bu sağlık harcamalarının da SGK tarafından karşılanmasını talep edebilmektedir (Kılıçoğlu, 2020, ss. 424-425).

\section{İş Kazasına Uğrayan Sigortalıya Yapılan Parasal Yardımlar}

Sosyal güvenliğin temel amaçlarından biri de sigortalılara bir ekonomik güvence sağlamaktır. Bu nedenle iş kazasına uğrayan, belli bir süre çalışamayan ve bu nedenle ücret kaybına uğrayan sigortalılara parasal yardımlar yapılmaktadır (Günay, 2020, ss. 520-521). Bu kapsamda sigortalının çalışamadığı dönemde yaşadığı ücret kayıpları telafi edilmektedir (Güzel vd., 2020, ss. 430-432). Bu şekilde sigortalının çeşitli risklere karşı korunması amaçlanmıştır (Alper ve Kılkış, 2017, ss.161-162).

$\mathrm{Bu}$ doğrultuda iş kazasına uğrayan sigortalıya, sigortalının iş göremezlik oranına göre parasal yardımlar yapılmaktadır (Akdeniz, 2014, s. 10). Bu nedenle iş kazasına uğrayan sigortalının iş kazası ve meslek hastalığı sigorta kolu kapsamında birtakım hakları bulunmaktadır. Ayrıca, sigortalının bu hakları kazanması için belli bir sigortalılık süresini doldurulması ve Kurum'a herhangi bir priminin bildirilmiş olması gerekmemektedir (Tuncay ve Ekmekçi, 2017, ss. 409-410).

\section{Geçici İş Göremezlik Ödeneği}

5510 sayılı Kanunun 16. maddesinde iş kazası veya meslek hastalığına uğrayan sigortalılara yapılacak parasal yardımlar arasında geçici iş göremezlik ödeneği de sayılmıştır. Ancak, iş kazasına uğrayan sigortalının geçici iş göremezlik ödeneğine hak kazanabilmesi için geçici iş göremez hale gelmesi gerekmektedir. 
Geçici iş göremezliğin tanımı, Sosyal Sigorta İşlemleri Yönetmeliği'’nin 38. maddesinin 1. fikrasında düzenlenmiştir. Buna göre geçici iş göremezlik;

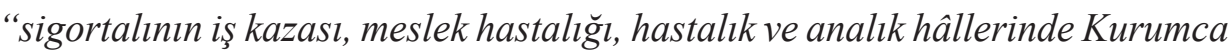
yetkilendirilen hekim veya sağlık kurulu raporlarında belirtilen istirahat süresince geçici olarak çalışamama hâlidir... "Aynı maddenin ikinci fikrasında da geçici iş göremezlik ödeneğinin tanımı yapılmıştır. Buna göre geçici iş göremezlik ödeneği; "iş kazası, meslek hastalığı, hastalık ve analık hâllerinde Kanunda belirtilen geçici iş göremezlik sürelerinde verilen ödenektir.” Ayrıca, 5510 sayılı Kanunun 18. maddesinde geçici iş göremezlik süresince sigortalıya günlük geçici iş göremezlik ödeneğinin verileceği düzenlenmiştir.

$\mathrm{Bu}$ doğrultuda, geçici iş göremez hale gelen sigortalı iyileşene kadar bir tedavi sürecine tabi tutulmaktadır. Tedavi devam ettiği sürece de sigortalıya geçici iş göremezlik ödeneği bağlanmaktadır (Tuncay ve Ekmekçi, 2017, ss. 410-411). Buna göre, geçici iş göremezlik ödeneği sigortalı iyileşene kadar ödenmektedir. Bu nedenle Yargıtay, geçici iş göremezlik için "iyileşme süresi”, "çalışılamayan süre" gibi kavramları sıklıkla telaffuz etmektedir (Y.17.HD, T.19.09.2019, E.2016/15584, K.2019/8246).

İş kazasına uğrayan sigortalının geçici iş göremezlik ödeneğinden faydalanabilmesi için olayın Kurum tarafından iş kazası olarak kabul edilmesi yeterli olup, bunun dışında başka bir koşul aranmamaktadır (Kaynak, 2018, s. 651). Buna göre, iş kazası nedeniyle iş göremezliğe uğrayan sigortalıya, iş göremediği süre boyunca prim ödeme gün sayısı şartı aranmaksızın geçici iş göremezlik ödeneği verilmektedir. Dolayısıyla Kurum olayı iş kazası olarak kabul ettiği takdirde geçici iş göremez hale gelen sigortalıya bu ödeme yapılmaktadır (Ttatr, 2017, s. 2152). Ancak, bağımsız çalışan sigortalıların geçici iş göremezlik ödeneğine hak kazanabilmesi için genel sağlık sigortası da dahil olmak üzere prim ve prime ilişkin herhangi bir borcunun bulunmaması gerekmektedir (Güzel vd., 2020, s. 427).

Geçici iş göremezlik ödeneği, Kurumca yetkili kılınan hekim veya sağlık Kurullarının düzenlediği istirahat raporlarına istinaden ödenmektedir (Elma, 2019, ss. 225-226). Bu bağlamda, düzenlenen rapor doğrultusunda iş kazası nedeniyle çalışma gücünden geçici yoksun kalan sigortalıya, çalışma gücünün geçici olarak kaybettiği dönemde her gün için ödeme yapılmaktadır (Görgöz, 2019, ss. 39-40). Bu şekilde işçinin çalışamadığ dönemde yaşadığ gelir kaybının telafisi amaçlanmaktadır (Y.21.HD, T.30.09.2013, E.2013/10568, 
K.2014/17684). Ayrıca, geçici iş göremezlik ödeneği belirlenirken iş kazasının yaşandığı tarih esas alınmaktadır (Tuncay ve Ekmekçi, 2017, s. 410). Zira Yargıtay geçici iş göremezlik ödeneğinin, iş kazalarında olayın, meslek hastalıklarında ise tedavinin başladığı tarihten itibaren çalışamaz duruma gelen sigortalıya raporlu olduğu dönem için ödendiğini ifade etmiştir (Y.21.HD, T.12.02.2019, E.2018/920, K.2019/886).

Geçici iş göremezlik ödeneğinin ne miktarda ödeneceği ve hesaplanmasında hangi kuralların uygulanacağ 5510 sayılı Kanunun 17. vd. maddelerinde ve Sosyal Sigorta İşlemleri Yönetmeliği'nin 40. maddesinde düzenlenmiştir.

5510 say1lı Kanunun 17. maddesine göre, "İ̧s kazasl, meslek hastalığ hastalık ve analı hallerinde verilecek ödeneklerin veya bağlanacak gelirlerin hesabına esas tutulacak günlük kazanç; iş kazasının veya doğumun olduğu tarihten, meslek hastalı̆̆ veya hastalı halinde ise iş göremezliğin başladiğ tarihten önceki oniki aydaki son üç ay içinde 80 inci maddeye göre hesaplanacak prime esas kazançlar toplamının, bu kazançlara esas prim ödeme gün sayısına bölünmesi suretiyle hesaplanır.."

Bu doğrultuda geçici iş göremezlik ödeneği sigortalının günlük kazancı baz alınarak hesaplanmaktadır. Günlük kazanç belirlenirken de, günlük kazanca dahil edilecek gelirlerin ayrıntılı şekilde gösterildiği 80. madde kapsamında hesaplamanın yapılması gerekmektedir.

Sigortalının günlük kazancının belirlenmesi açısından 5510 sayılı Kanunun 80. maddesi oldukça önemlidir. Zira 5510 sayılı Kanunun 80. maddesinde prime esas kazanç düzenlenmiştir. Buna göre, iş kazası halinde ödenecek geçici iş göremezlik ödeneğinin tutarı hesaplanırken, iş kazası tarihinden önceki 12 aydaki son 3 ay içinde sigorta primine esas kazançlar toplamının, bu kazançlara esas prim ödeme gün sayısına bölünmesi suretiyle hesaplanır. Ancak sigortalı 12 aylık dönemde çalışmamış ve ücret almamış ve sigortalı çalışmaya başladığı ay içinde iş kazası nedeniyle iş göremezliğe uğramışsa verilecek ödeneğin hesabında esas günlük kazanç; çalışmaya başladığı tarih ile iş göremezliğinin başladığı tarih arasındaki sürede elde ettiği prime esas günlük kazanç toplamının, çalıştığı gün sayısına bölünmesi suretiyle; çalışmaya başladığı gün iş kazasına uğramışsa aynı veya emsal işte çalışan benzeri bir sigortalının günlük kazancı esas alınarak hesaplama yapılır. 
Geçici iş göremezlik ödeneğine esas günlük kazanç hesaplanırken, prim, ikramiye ve bu nitelikteki arızi ödemeler dikkate alınmış ise ödeneğe esas alınacak günlük kazanç; ücret toplamının ücret alınan gün sayısına bölünmesiyle hesaplanacak günlük kazanca, \% 50 oranında bir ekleme yapılmak suretiyle ortaya çıan tutardan fazla olamayacaktır. Yargı veya idare mercilerince verilen karar gereğince yapılan ücret, ikramiye, zam, tazminat ve bu nitelikteki ödemelerden, ödeneğin hesabına esas alınan 3 aylık dönemden önceki aylara ilişkin olanlar göz önünde tutulmayacaktır.

Geçici iş göremezlik ödeneği hesaplanırken sigortalının günlük kazancı esas alınmaktadır. Ancak, günlük kazanç üzerinden sigortalıya yapılacak ödemenin oranı değişmektedir. Zira 5510 sayılı Kanunun 18. maddesinin 3. fikrasına göre, yatarak tedavi olan sigortalıya, sigortalının 17. maddeye göre hesaplanan günlük kazancının yarısı üzerinden, ayakta tedavisi yapılan sigortalıya ise, sigortalının 17. maddeye göre hesaplanan günlük kazancının üçte ikisi oranında geçici iş göremezlik ödeneğinin verilmesi gerektiği düzenlenmiştir.

$\mathrm{Bu}$ açıklamalardan hareketle geçici iş göremezlik ödeneği sigortalının günlük kazançlarından hareketle hesaplanmaktadır (Güzel vd., 2020, ss. 440-442). Primlerin hesabına esas tutulacak günlük kazanç, sigortalının, bir ay için prime esas tutulan kazancının otuzda birine tekabül etmektedir (Günay, 2020, ss. 521-522). Ancak Yargıtay işçilere geçici iş göremezlik ödeneğinin verilmesi gereken zamanlarda geçici iş göremezlik süresine rastlayan ulusal bayram, genel tatil ve hafta tatillerinin ödeme yapılan kurum veya sandıklar tarafindan geçici iş göremezlik ölçüsü üzerinden ödeneceğini, hastalık nedeni ile çalışılmayan günlerde Sosyal Sigortalar Kurumu tarafından ödenen geçici iş göremezlik ödeneği aylık ücretli işçilerin ücretlerinden mahsup edilmesi gerektiğini, bu şekilde işçinin iş göremediği dönemde ücretini tam alması halinde Kurumca ödenen iş göremezlik ödeneği ölçüsünde mükerrer ödemelerin önleneceğini kabul etmiştir (Y.9.HD, T.29.02.2012, E.2009/36116, K.2012/6418). Ayrıca Yargıtay, sigortalının bakiye ücret alacağı hesaplanırken geçici iş göremezlik ödeneğinin ödenip ödenmediğinin dikkate alınması gerektiğini, sigortalının bakiye ücret alacağı hesaplanırken geçici iş göremezlik raporu kapsamında geçici iş göremezlik ödeneğinden yararlanıp yararlanmadığının araştırılarak, ödenen miktarın mahsup edilmesi gerektiğini ifade etmiştir (Y.22.HD, T.18.03.2014, E.2014/5757, K.2014/6403). Bunun yanında Yargıtay, geçici iş göremezlik ödeneğinin tam olarak belirlenebilmesi 
için ayrıca sigortalıya uygulanan tedavi kapsamında sigortalının iyileşme süresinin ve mahiyetinin de kesin olarak tespit edilmesi gerektiğini ifade etmiştir (Y.17.HD, T.30.09.2019, E.2016/20125, K.2019/8681).

Bu doğrultuda, sigortalının geçici iş göremezlik ödeneğinden yararlanabilmesi için Sosyal Güvenlik Kurumunca görevlendirilen doktor veya sağlık kurumlarından istirahat raporunun alınmış olması gerekmektedir. İş kazası nedeniyle geçici iş göremez duruma gelen sigortalıya, geçici iş göremez olduğu her gün için Kurum geçici iş göremezlik ödeneği vermektedir (Tuncay ve Ekmekçi, 2017, s. 411).

Geçici iş göremezlik ödeneği, gerekli evrakların Kurum'a ulaşmasından itibaren yedi iş günü içinde ödenmektedir. Tedavi ve istirahat devam ettiği sürece sigortalı hak sahibi sayılmaktadır (Sözer, 2019, ss. 372-373). Ödemenin nasıl yapılacağı konusunda SGK yetkilidir. Ödemeler SGK ile anlaşması bulunan banka/bankalar aracılığıyla yapılmaktadır. Bu nedenle Yargıtay geçici iş göremezlik ödeneğinin ödenmesi hususunda Kurumun sorumlu olduğunu ifade etmiştir (Y.17.HD, T.23.09.2019, E.2016/18418, K.2019/8398).

Söz konusu açıklamalar ışığında geçici iş göremezlik ödeneğinin süresi belirlenirken tedavi süreci baz alınmaktadır. Buna göre, geçici iş göremezlik ödeneğinin sona ermesi açısından sigortalının sağlığına kavuşup kavuşmadığı, tedavi ve istirahatın bitip bitmediğine bakılarak karar verilmektedir (Güzel vd., 2020, ss. 410-411).

Bazı durumlarda geçici iş göremezlik ödeneklerinin birleşmesi gündeme gelmektedir. Bu durumda 5510 say11 kanunun 18. maddesinin 5. fikrasına göre, "Bir sigortalıda iş kazasl, meslek hastalığl, hastalık ve analık hallerinden birkaçı birleşirse, geçici iş göremezlik ödeneklerinden en yükseği verilir."

Geçici iş göremez hale gelen sigortalıya geçici iş göremezlik ödeneği Kurum tarafından ödenmektedir. Ancak, Kurum dişında işverenin de sigortalıya geçici iş göremezlik ödeneğini ödemesi mümkündür. İşverenin sigortalıya geçici iş göremezlik ödeneğini ödemesi halinde, işveren ödediğine dair belgeyi SGK'ye ibraz etmesi gerekir. İşverenin ödediğine dair belgeyi ibraz etmesi halinde SGK tarafından belirlenen geçici iş göremezlik ödeneği tutarı, işverenin SGK'ye olan borcundan, işverenin SGK'ye borcunun olmaması hâlinde ise ilk prim borcuna mahsup edilmektedir (Tuncay ve Ekmekçi, 2017, ss. 411-412). 
Bu açıklamalardan hareketle geçici iş göremezlik ödeneği sigortalının günlük kazancı üzerinden hesaplanmaktadır. Buna göre sigortalıya geçici iş göremezlik ödeneği kapsamında en fazla sigortalının vergi, sosyal sigorta, genel sağlık sigortası ve işsizlik sigortası primleri kesildikten sonra hesaplanan günlük net kazancı kadar ödeme yapılması mümkün olacaktır (Günay, 2020, ss. 579-580).

Geçici iş göremezlik ödeneği bu şekilde hesaplanmakla birlikte, geçici iş göremezlik ödeneğinin kesilmesi ya da belirlenen tutardan daha düşük bir tutar ödenmesi de mümkün bulunmaktadır. Zira 5510 sayılı Kanunun 22. maddesinde;

"Sigortalının aşağıldaki sayılan nedenlerden dolayı iş kazasına veya meslek hastalı̆̆ına uğraması, hastalanması, tedavi süresinin uzaması veya iş göremezliğinin artması hallerinde geçici iş göremezlik ödeneği veya sürekli iş göremezlik geliri;

a) Ceza sorumluluğu olmayanlar ile kabul edilebilir bir mazereti olanlar hariç, sigortalının iş kazası, meslek hastalı̆̆l, hastalık ve analık nedeniyle hekimin bildirdiği tedbir ve tavsiyelere uymaması sonucu tedavi süresinin uzamasına veya iş göremezlik oranının artmasına, malûl kalmasına neden olması halinde, uzayan tedavi süresi veya artan iş göremezlik oranı esas alınarak dörtte birine kadarı Kurumca eksiltilir.

b) Ceza sorumluluğu olmayanlar hariç, ağır kusuru yüzünden iş kazasına uğrayan, meslek hastalığına tutulan veya hastalanan sigortalının kusur derecesi esas alınarak üçte birine kadarı Kurumca eksiltilir.

c) Kasdî bir hareketi yüzünden iş kazasına ŭgrayan, meslek hastalı̆̆ına tutulan, hastalanan veya Kurumun yazll bildirimine răgmen teklif edilen tedaviyi kabul etmeyen sigortallya, yarısı tutarında ödenir.

d) Tedavi gördügü hekimden, tedavinin sona erdiğine ve çalışabilir olduğuna dair belge almaksızın çalışan sigortalıya geçici iş göremezlik ödeneği ödenmez, ödenmiş olanlar da yersiz yapılan ödeme tarihinden itibaren 96 ncı madde hükümlerine göre geri alınır..." şeklinde bir düzenleme getirilmiştir.

Geçici iş göremezlik ödeneği beş yıllık zamanaşımına tabidir. Buna göre geçici iş göremezlik ödemeğine hak kazanma tarihinden itibaren geçerli bir neden olmaksızın beş yıl içinde talep edilmemesi halinde geçici iş göremezlik ödeneği zamanaşımına uğramaktadır (Yazıcı ve Çetin, 2018, ss. 47-48). 


\section{Sürekli İş Göremezlik Geliri}

5510 sayılı Kanunun 16. maddesinde iş kazası veya meslek hastalığ 1 sigortasından sağlanan haklar arasında sürekli iş göremezlik geliri de sayılmıştır. Buna göre sigortalı, iş kazası nedeniyle en az \%10 meslekte kazanma gücünü yitirdiği takdirde, bu halin devamı süresince sigortalıya sürekli iş göremezlik geliri bağlanmaktadır (Tuncay ve Ekmekçi, 2017, ss. 410-411). Ancak, bu durumda, Kurumun yetkili kıldığı sağlik hizmet sunucularının sağlık kurulu tarafından düzenlenen raporlara istinaden sigortalıya sürekli iş göremezlik gelirinin bağlanması gerekmektedir (Güzel vd., 2020, ss. 369-370).

Sürekli iş göremez hale gelen sigortalının bedensel bütünlüğü zarar görmekle birlikte, sigortalının fiziki, psikolojik, duygusal veya entelektüel açıdan da bir kayba uğraması mümkündür (Narter, 2017, s. 286). Ayrıca, sigortalıya sürekli iş göremezlik gelirinin bağlanması için sigortalının iş kazasına uğradığı sırada en az \%10 meslekte kazanma gücünü yitirmesi gerekmektedir (Sözer, 2019, s. 367). Ancak sigortalının icra ettiği meslekte, en az \%10 meslekte kazanma gücünü yitirmesi gerekmektedir (Topaloğlu, 2014, ss. 160-161).

Bu doğrultuda, iş kazasına uğrayan sigortalının meslekte kazanma gücünün \%10'un altında olması halinde sigortalıya sürekli iş göremezlik gelirinin bağlanması söz konusu değildir (Güneren, 2020, ss. 737-738; Nomer, 2017, s. 236).

Geçici iş göremez hale gelen sigortalının sonradan sürekli iş göremez hale gelmesi de mümkündür. Bu durumda geçici iş göremezlik ödeneğinin sona erdiği tarihi takip eden ay sürekli iş göremezlik gelirinin bağlanması gerekmektedir. Ancak, sigortalıda geçici iş göremezlik tespit edilmeden sürekli iş göremezlik tespit edilmişse, Kurumca yetkilendirilen sağlık hizmeti sunucularının sağlik kurullarının sigortalıya sürekli iş göremezlik raporu verdiği tarihi takip eden ay başında sürekli iş göremezlik geliri başlamaktadır (SSGSSK m. 19).

Yargıtay'a göre, sigortalının iş kazasına uğraması halinde 5510 sayılı Kanunun 19. maddesine gidilmesi gerekmektedir. Buna göre, iş kazası neticesinde oluşan hastalık ve özürler nedeniyle Kurum tarafından yetkili kılınan sağlık hizmet sunucularının sağlık kurullarının düzenlediği raporlara istinaden iş göremezlik oranı en az \%10 azalan sigortalılara Kurum sağlık kurulu sürekli iş göremezlik geliri bağlamaktadır (Y.21.HD. T.25.02.2013, 15714/3292). Bu nedenle sigortalıda oluşan sürekli iş göremezlik oranının 
tespiti Kurum tarafindan yapılmaktadır ((Y.21.HD, T.01.02.2016, E.2016/18876, K.2016/853). Yargıtay sigortalının en az \% 10 iş görmez olduğunun tespiti halinde, kaza tarihini takip eden ay başından itibaren gelir bağlanması gerektiğini kabul etmiştir (Y.10.HD, T.18.09.2019, E.2019/191, K.2019/6229). Ancak, Yargıtay farklı işverenler yanında çalı̧̧ı̧̧ sigortalının farklı işverenler yanında çalıştığı sırada ayrı ayrı iş kazalarına uğraması halinde, bu iş kazalarında sigortalının ayrı ayrı \% 10'un altında iş göremezliğe uğramış olması durumunda, sigortalının iş göremezlik oranının toplamda \%10'u geçmesi halinde sigortalıya sürekli iş göremezlik ödeneğinin bağlanabileceğini, bu halde her bir işverenin kendi kusuru oranında sigortalıya bağlanan sürekli iş göremezlik ödeneğinin peşin sermaye değeri üzerinden sorumlu olacağını kabul etmiştir (Y.10.HD. T.03.10.2000, E.2000/5889, K.2000/5884). Bunun yanında Yargitay, 5510 sayılı Kanunun 95. maddesine göre, kazaya uğrayan sigortalının yurt dışında tedavi edilmesi için yapılacak sevklerde, sigortalıya iş göremezlik ödeneklerinin verilmesine ilişkin raporlar ile sigortalının iş göremezlik oranını gösteren sağlık kurulu raporlarının usul ve esaslarının yeniden düzenlenmesini SGK'nin istemeye yetkili olduğunu belirtmiştir (Y.21.HD, T.26.03.2013, E.2013/22186, K.2013/5761). Buna ek olarak, Yargıtay iş kazasına uğrayan sigortalılar açısından sürekli iş göremezlik hallerinde mesleki kazanma gücü kayıp oranının Kurumca çıkartılacak yönetmelikle belirlenebileceğini kabul etmiştir (Y.21. HD, T.25.02.2013, E.2013/15714, K.2013/3292).

Sigortalının iş göremezlik oranının \%10 ila \%99 arasında olması halinde sürekli kısmi iş göremezlik söz konusu olmakta iken, sigortalının iş göremezlik oranının \%100 olması halinde ise, sigortalı sürekli tam iş göremez hale gelmektedir (SSIY m. 45/7).

5510 sayı11 Kanunun 19. maddesinin 3. fikrasına göre, “...Sürekli iş göremezlik geliri, sigortalının mesleğinde kazanma gücünün kaybı oranına göre hesaplanır. Sürekli tam iş göremezlikte sigortalıya, 17 nci maddeye göre hesaplanan aylık kazancının \% 70'i oranında gelir bağlanır. Sürekli kısmî iş göremezlikte sigortalıya bağlanacak gelir, tam iş göremezlik geliri gibi hesaplanarak bunun iş göremezlik derecesi oranındaki tutarı kendisine ödenir. Sigortall, başka birinin sürekli bakımına muhtaç ise gelir bağlama oranı \% 100 olarak uygulanır.."

Bu doğrultuda 5510 sayılı Kanunun 19. maddesinin 3. fikrasında, sürekli tam iş göremezlikte sigortalıya, hesaplanan aylık kazancının \% 70’i oranında 
gelir bağlanması gerektiği ve sigortalının bir başkasının bakımına sürekli muhtaç olması halinde $\% 100$ oranında gelir bağlanması gerektiği düzenlenmiştir. Buradan hareketle, sürekli kısmi iş göremezlik gelirinde ise, $\% 70$ oranında iş göremezlik derecesine karşılık gelen miktarı kadar ödemenin yapılması gerekmektedir. Aynı şekilde sigortalı bir başkasının sürekli bakımına muhtaç hale geldiği takdirde ise gelir \% 100 oranında bağlanacaktır.

Sigortalının tam iş göremez hale gelmesi durumunda sürekli iş göremezlik geliri: Günlük kazanç $x 30 x \% 70$,

Sigortalının kısmi iş göremez hale gelmesi durumunda sürekli iş göremezlik geliri: Günlük kazanç $x 30 \times \%$ \% 70 SiD (sürekli iş göremezlik derecesi) şeklinde hesaplanır.

Sürekli iş göremezlik oranı tespit edildikten sonra zaman içinde bu oranında bir değişiklik yaşanması mümkündür. Sürekli iş göremezlik oranının değişmesine bağlı olarak sürekli iş göremezlik ödeneğinin miktarı da değişmektedir. $\mathrm{Bu}$ durumda sigortalı Kurum'a başvurarak sürekli iş göremezlik oranındaki değişikliğin tespitini isteyebilmektedir. Bu durumda sigortalının sürekli bir başkasının bakımına muhtaç hale gelmesi de mümkün bulunmaktadır (Mülayim, 2011, s. 98).

Yargıtay, iş kazasına uğrayan sigortalının tam iş göremez duruma gelmesi halinde, sigortalıya sağlanacak yardımlar arasında bakıcı ve bakım giderlerinin de bulunması gerektiğini, ancak hayatın olağan akışı açısından sigortalının yakınlarının sigortalıya bakmasının olağan ve mümkün olması nedeniyle sigortalıya gelir bağlanırken bu durumun da dikkate alınması gerektiğini ifade etmiştir (Y21HD. T.17.06.2013, E.2013/8542, K.2013/12717).

Yargıtay, bu durumda iş kazasına uğrayan sigortalının aile içi bakım dayanışmasından yararlanabileceğini, bu nedenle bilirkişi raporuna göre bakıcı giderinden uygun oranda hakkaniyet indiriminin yapılması gerektiği yönünde karar vermiştir (Y.21.HD, T.22.10.2019, E.2018/3679, K.2019/6392).

5510 sayılı Kanunun 19. maddesine göre, sürekli iş göremezlik geliri bağlanacak sigortalıya önceden geçici iş göremezlik ödeneği bağlanması halinde, geçici iş göremezlik ödeneğinin sona erdiği tarihten itibaren sürekli iş göremezlik ödeneğinin bağlanacağı, ancak sürekli iş göremez hale gelen sigortalıya daha önce geçici iş göremezlik ödeneği verilmemişse bu durumda 
sigortalının sürekli iş göremez hale geldiğini gösteren sağlık kurulu raporunun düzenlenme tarihini izleyen ay başından itibaren sürekli iş göremezlik ödeneği ödenmeye başlayacak ve bu gelir sigortalıya her ay peşin olarak ödenecektir. Ayrıca sürekli iş göremezlik geliri bağlanabilmesi için sigortalının iş kazasına uğradığ 1 ve sürekli iş göremez hale geldiği işte aktif olarak çalışması şart değildir

SSIYY m.41/3 hükmüne göre, "Sürekli iş göremezlik geliri bağlanabilmesi için, sigortalının çalıştı̆̆ işten ayrılması, iş yerini kapatması veya devretmesi şartı aranmaz. Örneği Kurumca hazırlanacak tahsis talep dilekçesini doğrudan Kuruma vermesi veya posta yoluyla ya da elektronik ortamda göndermesi gerekir."

$\mathrm{Bu}$ doğrultuda, iş kazasına uğrayan sigortalının sürekli iş göremezlik gelirine hak kazanabilmesi için, sigortalının uğramış olduğu iş kazası nedeniyle belli bir oranın üzerinde iş göremez hale gelmesi ve sigortalının bu durumunu gösteren sağlık raporu almas1 gerekmektedir (Görgöz, 2019, s. 45).

Yargıtay SGKnin iş kazasına uğrayan sigortalının iş göremezlik oranını gösteren bir rapor düzenlemesi üzerine, yargılama sırasında da başka bir kurumun sigortalının iş göremezlik oranını gösteren bir rapor düzenlemesi halinde iş göremezlik oranının belirlenmesi açısından bu raporların birbiriyle çelişmemesi gerektiğine hükmetmiştir (Y.21.HD. T.18.03.2013, E.2013/20004, K.2013/4818). Ayrıca Yargıtay, iş kazasına uğrayan sigortalının uğramış olduğu zararların giderilmesi açısından maddi tazminat davası açılmış olması halinde, sigortalıda oluşan iş göremezlik oranının tazminat miktarını doğrudan etkileyeceğini belirtmiştir (Y.21.HD. T.26.03.2013, E.2013/22186, K.2013/5761). Bunun yanında Yargıtay, iş kazası sonucunda sigortalı sürekli iş göremez hale gelmemiş olsa dahi, iş kazası nedeniyle sigortalının acı ve üzüntü duymasına bağlı olarak ruh bütünlüğünün ihlal edilmesi nedeniyle manevi tazminat talebinde bulunabileceğine de hükmetmiştir (Y.21.HD, T.12.02.2019, E.2018/920, K.2019/886). Zira manevi tazminat davas1 ile davacının duyduğu acı ve elemin kısmen de olsa giderilmesi amaçlanmaktadır. $\mathrm{Bu}$ nedenle kişinin beden bütünlüğünün ne oranda zarar gördüğüne bakılmamaktadır (Y.17.HD, T.16.07.2018, E.2017/4534, K.2018/7227).

5510 sayılı Kanunun 19. maddesinin 4. fikrasına göre, "4 üncü maddenin birinci fikrasının (b) bendine göre sigortalı sayılanlara, sürekli iş göremezlik 
geliri bă̆lanabilmesi için, kendi sigortalılı̆̆ından dolayı, genel să̆lık sigortası dahil prim ve prime ilişkin her türlü borçlarının ödenmiş olması zorunludur." Buna göre, bağımsız çalışan sigortalıların da sürekli iş göremezlik geliri alma hakkı bulunmaktadır. Ancak, bağımsız çalışanların genel sağlık sigortası dahil prim ve prime ilişkin Kuruma herhangi bir borcunun bulunmaması gerekmektedir. Anayasa Mahkemesi de 5510 sayılı Kanunun 19. maddesinin 4. fikrasında yer alan bu düzenlemeyi isabetli bulmuştur. Anayasa Mahkemesi de bağımsız çalışan sigortalıların sürekli iş göremezlik geliri alabilmesi için bağımsız sigortalıların genel sağlık sigortası dahil prim ve prime ilişkin Kuruma herhangi bir borcunun bulunmaması gerektiğini kabul etmiştir (AYM, T.15.12.2006, 111/112).

Kanaatimizce Anayasa Mahkemesi'nin bu yaklaşımı yerinde değildir. Zira sırf bağımsız çalışıyor olması nedeniyle bir sigortalının bu haktan yararlanmasını kısıtlamaya yönelik anlayış sosyal güvenlik anlayışı ile örtüşmemektedir. Dolayısıyla iş kazasına uğrayan kişinin sürekli iş göremezlik ödeneği alabilmesi için sigortalı olması yeterlidir.

5510 sayılı Kanunun 22. maddesine göre Kurumun yapacağı kontrol muayenesini sigortalının haklı bir sebep olmamasına rağmen yaptırmaması, hekim tarafindan uyulması istenilen tavsiyeleri yerine getirmemesi üzerine tedavi süresinin daha da uzamasına, iş göremezlik oranının daha da artmasına sebebiyet vererek tedavi süresinin uzaması ve iş göremezlik oranın artmasına bağlı olarak Sosyal Güvenlik Kurumu tarafından sigortalının sürekli iş göremezlik gelirinin dörtte birine kadar eksiltilmesi mümkün bulunmaktadır.

\section{Aylık ve Gelir Almaya Hak Kazanan Sigortalıya Uygulanacak Hükümler}

İş kazasına uğrayan sigortalıya geçici iş göremezlik ödeneği bağlanabileceği gibi sürekli iş göremezlik geliri de bağlanabilir. Geçici iş göremezlik ödeneği tedavi sürecince verilen bir ödenektir (Tuncay ve Ekmekçi, 2017, ss. 410-411). Bu nedenle geçici iş göremezlik ödeneği kısa bir süre ile sınırlı olarak verilmektedir (Elma, 2019, ss. 226-227). Ancak sürekli iş göremezlik geliri, oldukça uzun bir süre boyunca ödenen bir gelirdir (Yazıcı ve Çetin, 2018, ss. 40-41). Bu nedenle sürekli iş göremezlik geliri alan sigortalının sürekli iş göremezlik derecesinde bir değişiklik olması halinde, sigortalı kendisine bağlanan gelirde bir değişiklik yapılmasını talep edebilmektedir. Buna göre sigortalının sürekli iş göremezlik derecesinin artması ya da sigortalının sürekli bir başkasının yardımına muhtaç 
olması halinde, sigortalı gelirinde bir değişiklik yapılmasını Kurumdan talep edebilmektedir (Tuncay ve Ekmekçi, 2017, s. 411).

İş kazasına uğrayan sigortalıya malullük aylığının bağlanması da mümkün bulunmaktadır (Baycık, 2013, s. 130). Ayrıca, malullük aylığı uzun vadeli bir sigorta koludur ve malullük aylığının bağlanması için birtakım şartların birlikte bulunması gerekmektedir. Buna göre, iş kazasına uğrayan sigortalı için 1800 gün uzun vadeli sigorta kolu primi bildirilmiş, iş kazasına uğrayan sigortalı en az 10 yıl sigortalı çalışmış ve sigortalı iş kazası nedeniyle en az \%60 oranında çalışma gücünü yitirmişse sigortalıya malullük aylığının da bağlanması mümkün bulunmaktadır.

Bu doğrultuda, iş kazasına uğrayan sigortalıya birtakım ödemelerin yapılması mümkün bulunmaktadır (Akdeniz, 2014, s. 10). Ancak, bu durumda sigortalıya aynı anda bir ödemenin yapılması ve bir aylığın bağlanması gündeme gelebilir. Bu durumda gelir ve aylıkların aynı anda sigortalıya bağlanıp bağlanmayacağı sorusu akla gelmektedir. Bu gibi durumlarda 5510 sayılı Kanunun 54. maddesinin uygulanması yerinde olacaktır.

5510 sayılı Kanunun 54. maddesinin c fikrasına göre, "Malûllük, yaşlılık ve ölüm sigortaları ile iş kazası ve meslek hastalığı sigortasından hak kazanılan aylık ve gelirler birleşirse, sigortallya veya hak sahibine bu aylık veya gelirlerden yüksek olanın tamamı, az olanın yarısı, eşitliği halinde ise iş kazası ve meslek hastalığından bă̆lanan gelirin tümü, malûllük ve yaşlılık aylı̆̆ının yarısı bağlanır."

Bu kapsamda, iş kazasına uğrayan sigortalının sürekli iş göremezlik ödeneği ile malullük aylığına birlikte hak kazanması halinde sürekli iş göremezlik ödeneği ile malullük aylığından hangisi yüksek ise, yüksek olanın tamamı, az olanın ise yarısının ödenmesi gerekmektedir. Buna karşın malullük aylığı ile sürekli iş göremezlik ödeneğinin eşit çıkması durumunda ise, sürekli iş göremezlik ödeneğinin tamamı ödenirken, malullük aylığının ise yarısının ödenmesi gerekmektedir.

\section{İş Kazasına Uğrayan Sigortalının Ölümü Halinde Hak Sahiplerine Tanınan Haklar}

Hak sahipleri, sigortalının ölümü veya sürekli iş göremezlik geliri ya da malûllük, vazife malûllüğü, yaşlılık aylığı almakta olan sigortalının ölümü 
halinde, gelir, aylık veya toplu ödeme almaya hak kazanan eş, çocuk, ana ve baba olan kimselerdir (Elma, 2019, ss.118-119).

İş kazası geçiren sigortalının ölümü ile birlikte, sigortalının geride bıraktığ 1 hak sahipleri zor duruma düşebilmektedir. Bu nedenle hak sahiplerine bazı yardımların yapılması gerekmektedir (Mülayim, 2011, s. 101).

Sigortalının ölümü ile birlikte, sigortalının geride bıraktığı, eş, çocuk, ana ve baba hak sahibi olan kimselerdir. Bunlar dışında ölen sigortalının geride bıraktığı kardeş, amca, dayı teyze gibi akrabalar hak sahibi olarak kabul edilmemektedir. Bu kişilere sigortalı hayattayken bakmakla yükümlü olsa dahi, sigortalı öldüğünde bu kişiler sosyal güvenlik sistemi içinde hak sahibi sıfatını kazanmamaktadır.

Bu doğrultuda, iş kazasına uğrayan sigortalının ölümü halinde hak sahiplerinin de birtakım hakları bulunmaktadır. Zira 5510 sayılı Kanunun iş kazası veya meslek hastalığından sağlanan haklar başlıklı 16. maddesinde iş kazası veya meslek hastalığı sonucu ölen sigortalının hak sahiplerine birtakım haklar tanınmıştır. Bunlar, cenaze ödeneği, hak sahiplerine gelir bağlanması, kız çocuklarına evlenme ödeneği verilmesi şeklindedir. Buna göre hak sahiplerine kısa vadeli sigortalı kolu kapsamında birtakım ödemeler yapılmaktadır. Ancak, iş kazası nedeniyle ölen sigortalının hak sahiplerine uzun vadeli sigorta kolu kapsamında aylık bağlanması da mümkün bulunmaktadır.

$\mathrm{Bu}$ açıklamalardan hareketle iş kazası nedeniyle ölen sigortalının hak sahiplerine birtakım parasal yardımlar yapılmaktadır (Güzel vd., 2020, s. 375 376). Ayrıca, ölen sigortalının hak sahiplerine sağlık yardımlarının yapılması da mümkün bulunmaktadır (Baybora, 2013, s. 334). Buna göre hak sahipleri kanunda belirtilen yardımları isteyebilmektedir. Ancak, hak sahiplerinin kanunda belirtilen yardımlar dışında başkaca bir yardımı Kurumdan talep etmesi söz konusu değildir (Çenberci, 1985, ss. 396-397).

\section{Ölüm Geliri}

İş kazasına uğrayan sigortalının ölümü halinde hak sahiplerinin ölüm geliri alması mümkün bulunmaktadır (Tuncay ve Ekmekçi, 2017, s. 413). Ölüm geliri 5510 sayılı Kanun kapsamında kısa vadeli sigorta kolları arasında düzenlenmiştir. $\mathrm{Bu}$ doğrultuda ölüm gelirinden ne anlaşılması gerektiğini ele almak isabetli olacaktır. 
Ölüm geliri, iş kazasına uğrayan sigortalının ölümü halinde hak sahiplerine yapılan sürekli ödemelerdir (Özdemir, 2008, s. 5). Ayrıca, ölüm gelirinin bağlanması açısından ölen sigortalının sigortalılık süresi veya prim gün sayısı gibi şartları taşıması da gerekmemektedir (Keleş, 2015, s. 215; Balcı, 2019, ss. 96-96). Bu nedenle işe girdiği ilk gün iş kazası sonucu ölen sigortalının geride bıraktığı hak sahiplerine de ölüm geliri bağlanmaktadır (Mülayim, 2011, s. 101). Ancak, iş kazasına uğrayan sigortalı kendi adına bağımsız çalışan sigortalı ise, hak sahiplerinin genel sağlık sigortası dahil prim ve prime ilişkin bir borcunun bulunmamas1 gerekmektedir (Baybora, 2013, s. 335).

Sigortalı iş kazası veya meslek hastalı̆̆ı nedeniyle hayatını kaybetmişse ölen sigortalının hak sahiplerine iş kazası ve meslek hastalığı sigorta kolundan gelir bağlanmaktadır (Balc1, 2019, ss. 108-110). Bu nedenle hak sahiplerine ölüm gelirinin bağlanması için ölümün iş kazası veya meslek hastalığından kaynaklanması gerekmektedir (Göktaş, 2012, 209).

Bu doğrultuda, iş kazasına uğrayan sigortalıya sürekli iş göremezlik geliri bağlanmış ve sigortalı sürekli iş göremezlik geliri almakta iken ölmüşse bu durumda hak sahiplerine ölüm gelirinin bağlanması mümkün bulunmaktadır (Olgaç vd, 2011, s 98). Ancak burada sürekli iş göremezlik geliri almakta iken ölen sigortalının hak sahiplerine bağlanacak gelir açısından ölen sigortalının meslekte kazanma gücünün yüzde kaç olduğu önem taşımaktadır (Balc1, 2019, ss. 105-107).

5510 sayıl1 Kanunun 20. maddesine göre,

“..IŞ kazası veya meslek hastalığı sonucu meslekte kazanma gücünü \% 50 veya daha fazla oranda kaybetmesi nedeniyle sürekli iş göremezlik geliri bağlanmış iken ölenlerin, ölümün iş kazası veya meslek hastalı̆̆ına bağlı olup olmadı̆̆ına bakılmaksızın birinci fikraya göre belirlenen tutar, 34 üncü madde hükümlerine göre hak sahiplerine gelir olarak bağlanır. İs kazası veya meslek hastalı̆̆ sonucu meslekte kazanma gücünü \% 50 oranının altında kaybetmesi nedeniyle sürekli iş göremezlik geliri bağlanmış iken ölenlerin, ölümün iş kazası veya meslek hastalığına bağlı olmaması halinde sigortalının almakta olduğu sürekli iş göremezlik geliri, 34 üncü madde hükümlerine göre hak sahiplerine gelir olarak bağlanır..."

Bu çerçevede iş kazasına uğrayan ve sürekli iş göremezlik ödeneği alan sigortalının, meslekte kazanma gücünün \% 50'nin altında olmasına göre farklı, 
$\% 50$ ve üzerinde olmasına göre farklı bir değerlendirme yapılmaktadır. Buna göre, sigortalı \% 50'nin altında iş göremez hale gelmesi nedeniyle gelir almakta iken ölmüşse ve sigortalının ölümü iş kazası ve meslek hatalığından kaynaklanmamakta ise hak sahiplerine kısmi aylık bağlanmaktadır. Ancak, sigortalı \% 50'nin altında iş göremez olması nedeniyle gelir almakta iken iş kazası ve meslek hastalığı nedeniyle hayatını kaybetmişse hak sahiplerine tam aylık bağlanacaktır. Ancak, sigortalı \% 50 ve \% 50 üzeri iş göremez hale gelmesi nedeniyle gelir almakta iken ölmüşse, sigortalının ölümü iş kazası veya meslek hastalığına bağlı olsun ya da olmasın hak sahiplerine tam aylık bağlanmaktadır (Alper, 2015, s. 258). Dolayısıyla, iş kazası nedeniyle ölen sigortalının hak sahiplerinin kendilerine ölüm geliri tahsis edilmesini talep etme hakk1 bulunmaktadır (Topaloğlu ve Çınkı, 2014, s. 178). Bu şekilde, hak sahiplerine tahsis edilen ölüm geliri ile hak sahiplerine ekonomik açıdan bir koruma sağlanmaktadır. (Yazıcı ve Çetin, 2018, ss. 51-52).

\section{Ölüm Aylığı}

İş kazasına uğrayan sigortalının ölümü halinde hak sahiplerine ölüm aylığı bağlanması da mümkün bulunmaktadır (Tuncay ve Ekmekçi, 2017, s. 314;Balc1, 2019, ss. 81-82). Bu nedenle ölüm olayının gerçekleşmesi ile birlikte hak sahiplerine ölüm aylığının bağlanması söz konusu olabilecektir (Civan, 2015, s. 48). Yargıtay bu şekilde hak sahiplerinin geleceğinin güvence altına alınabileceğini ifade etmiştir (Y10.HD, T.27.03.2012, E.2012/3196, K.2012/5975).

5510 sayılı Kanun kapsamında ölüm geliri kısa vadeli sigorta kolu içinde düzenlenmişken, ölüm aylığı uzun vadeli sigorta kolu içinde düzenlenmiştir. Buna göre, ölüm aylığından ne anlaşılması gerektiğini ele almak isabetli olacaktır. Bu bağlamda, ölüm aylığı bir uzun vadeli sigorta kolu olan ölüm sigortasından yararlanan sigortalının iş kazası sonucu ölmesi halinde hak sahiplerine bağlanan aylıktır (Balc1, 2019, s. 83; Güzel vd., 2020, ss. 379-380). Bu şekilde sigortalının ölümü üzerine hak sahiplerinin maddi sıkıntı çekmemeleri ve geçimlerini sürdürebilmeleri amaçlanmıştır (Yorulmaz, 2010, s. 289).

5510 sayılı Kanunun 34. maddesine göre, iş kazası nedeniyle ölen sigortalının dul eşine ölenin aylık gelirinin \% 50'si aylık olarak bağlanabilmektedir. Ancak, dul eşin aylık bağlanmış çocuğunun bulunmaması halinde ve dul eşin 5510 sayılı Kanun kapsamında veya yabancı ülke mevzuatı uyarınca çalışmaması 
veya dul eşe dul eşin kendisinin sigortalı olması sebebiyle gelir veya aylık bağlanmamış olması halinde dul eşe $\% 75$ oranında aylık bağlanacaktır.

Sigortalının ölümü halinde ölüm tarihinde ölen sigortalı ile geride kalan eş arasında MK esaslarına uygun şeklide resmi nikahın bulunması gerekmektedir (Tuncay ve Eknekçi, 2017, ss. 413-414). Ölen sigortalı ile geride kalan eş arasında resmi evlilik bağının bulunmaması halinde hak sahibi sıfatı oluşmamaktadır (Balc1, 2019, s. 83). Buna göre evlilik yasal olmazsa, birlikte yaşam ya da dini nikah gibi durumlarda geride kalan eşe aylık bağlanması mümkün olmayacaktır. Sigortalının dul eşi evlenirse bu aylık kesilir, ancak aylığın kesilmesine yol açan evlenme son bulunca aylık yeniden bağlanır. Sonraki eşinden de gelir almaya hak kazanırsa fazla olan gelir ödenir (Mutlay, 2014, ss. 284-285).

Yargıtay, TMK kapsamında geçerli bir evlilik ilişkisinin bulunması gerektiğini belirterek, evlilik dışı birlikte yaşayan kişilerin ölüm aylığı açısından hak sahibi olamayacağını, bu kişilerin hak sahibi olan “eş" sıfatını taşımayacağını kabul etmiştir (Y10.HD, T.01.03.2010, E. 2008/18155, K. 2010/2758).

Ölen sigortalının dul eşi evlendiği taktide bağlanan bu gelir kesilmektedir. Ancak, gelirin kesilmesine yol açan evlenme son bulduğunda yeniden bu gelir bağlanmaktadır.

5510 say1lı Kanunun 56. maddesinin 2. fikrasında, "Eşinden boşandiğ l halde, boşandı̆̆ eşiyle fiilen birlikte yaşadığı belirlenen eş ve çocukların, bağlanmış olan gelir ve aylıkları kesilir. Bu kişilere ödenmiş olan tutarlar, 96 ncı madde hükümlerine göre geri alınır." ş̧eklinde bir düzenleme bulunmaktadır. Kanaatimizce bu düzenleme yerindedir. Bu şekilde kanun koyucu gelir elde edebilmek amacıyla eşlerin muvazaalı şekilde boşanmalarını engellemek istemiştir.

Sigortalının çocukları da ölüm aylığı almaya hak kazanmaktadır. Ancak, sigortalının üvey çocuğuna ölüm aylığı bağlanması söz konusu değildir (Civan, 2015, s. 115). Zira sigortalı tarafından evlat edinilmiş, tanınmış, soybağ düzeltilmiş veya babalığı hükme bağlanmış çocuklar ile gerekli koşulların varlığı halinde sigortalının ölümünden sonra doğan çocuklarına ölüm aylığının bağlanması mümkün bulunmaktadır (SSGSSK m. 34/3). 
5510 sayılı Kanunun 34. maddesine göre çocuklara bağlanacak gelir oranları da farklılık göstermektedir. Ölen sigortalının çocukları 5510 sayılı Kanun kapsamında ya da yabancı ülke mevzuatına göre çalışmamakta veya çocuklar kendi çalışmaları nedeniyle gelir ve aylık almamakta ise 18 yaşına kadar, ölenin çocukları lise ve dengi eğitim almakta ise 20 yaşına kadar, ölenin çocukları yükseköğrenim yapmakta ise, 25 yaşına kadar \% 25 oranında aylık bağlanır. Ayrıca, ölen sigortalının Kurum Sağlık Kurulu kararı ile çalışma gücünü en az \% 60 oranında yitiren malûl çocuklarının bulunması halinde veya ölen sigortalının her ne yaşta olursa olsun evli olmayan, evli olmasına karşın sonradan boşanmış veya dul kalmış kızlarına da her biri için \% 25 oranında aylık bağlanmaktadır. Bunun yanında, çocuklardan sigortalının ölümü ile anasız ve babasız kalan veya daha sonra bu duruma düşenlerle, ana ve babaları arasında evlilik bağı bulunmayan veya sigortalının öldüğü tarihte evlilik bağı bulunmakla birlikte ana veya babaları sonradan evlenenler ile kendisinden başka aylık alan hak sahibi bulunmayanların her birine $\% 50$ oranında aylık bağlanmaktadır. Buna ek olarak, hak sahiplerine bağlanacak aylıkların toplamının hiçbir zaman sigortalıya bağlanacak aylığın tutarını geçmesi söz konusu değildir. Buna göre, ölen sigortalının en az \% 60 oranında çalışma gücünü yitiren ve malûl olan çocukları, malûllük oranını gösteren raporun düzenlendiği tarihi takip eden bir sonraki ay başında aylık almaya hak kazanmaktadır (Topaloğlu ve Çınkı, 2014, s. 178).

İş kazası veya meslek hastalığı nedeniyle ölen sigortalının hak sahibi kız çocuklarına, bu kimselerin çalışmadıkları, evlenmedikleri ve Sosyal Güvenlik Kurumlarından gelir ve aylık almadıkları süre zarfında yaşa bakılmaksızın aylık bağlanmaktadır (Mülayim, 2011, s. 105). Ancak kız çocukları çalışmaya başladıklarında, evlendiklerinde veya Sosyal Güvenlik Kurumu'ndan kendi adlarına bir gelir ya da aylık bağlanması halinde bağlanan aylık kesilmektedir (Balc1, 2019, ss. 94-95).

Ölen sigortalının ana ve babasına da gelir bağlanması mümkün bulunmaktadır. Ancak, bu gelirin bağlanabilmesi için ölen sigortalının eşine ve çocuklarına yapılan paylaşımdan sonra artan hissenin bulunup bulunmadığı önem taşımaktadır (Tuncay ve Ekmekçi, 2017, ss. 416-417). Zira ölen sigortalının geride bıraktığı eşi ve çocukları öncelikli gruptur (Pehlivan, 2020, ss. 80-82). Bir başka ifadeyle, ölen sigortalının eşi ve çocuklarına gelir bağlandıktan sonra gelirde bir pay kalmışsa ölen sigortalının ana ve babasına kalan bu pay gelir olarak bağlanmaktadır (Civan, 2015, ss. 99-100;Balc1, 2019, ss. 92-93). 
5510 sayılı Kanunun 34. maddesine göre, iş kazasına uğrayan sigortalının ölümü halinde sigortalının ana ve babasına gelir bağlanabileceği düzenlenmiştir. Ancak, bu gelirin bağlanması için bazı şartlar aranmıştır. Buna göre, ölen sigortalının ana ve babasının 65 yaşının altında veya 65 yaşının üstünde olmasına göre ikili bir ayrım yapılmaktadır. Sigortalının ana ve babasının 65 yaşın altında olması halinde, ana ve babaya gelir bağlanabilmesi için hak sahibi eş ve çocuklardan artan bir hissenin bulunması gerekmektedir. Bu durumda hak sahibi eş ve çocuklardan artan bir hissenin bulunmaması halinde 65 yaşı altı ana ve babaya aylık bağlanması söz konusu olmayacaktır. Ancak, ölenin ana ve babası 65 yaşının üstünde ise, artan bir hisse olmasa dahi, ana ve babaya aylık bağlanabilmektedir. Bunun yanında ölüm gelirinin bağlanabilmesi için bir koşulun daha varlığı aranmaktadır. Buna göre, ana ve babanın her türlü kazanç ve irattan elde ettiği gelirlerinin asgari ücretin net tutarından daha az olması gerekmektedir. Buna ek olarak, ölenin ana ve babasına diğer çocuklarından almaya hak kazandıkları gelir ve aylıklar dışında başkaca bir gelir ve aylık bağlanmamış olması gerekmektedir. Bu koşulların varlığı halinde ölen sigortalının ana ve babasına gelirin $\% 25$ 'i oranında buna göre ana ve babaya ayrı ayrı \%12,5 oranında gelir bağlanacaktır. Daha önce belirttiğimiz üzere ölenin ana ve babasının 65 yaşının üstünde olması halinde artan hisse oranının bulunup bulunmadığına bakılmayacaktır.

$\mathrm{Bu}$ doğrultuda ölen sigortalının ana ve babasının ölüm gelirine hak kazanabilmesi için artan hisse oranının bulunması gerekmektedir (Mutlay, 2014, s. 292). Ancak, şu husus da belirtilmelidir ki, sigortalının öldüğü tarihte artan hisse oranı bulunmamakla birlikte, daha sonradan artan hisse oranının ortaya çıkması halinde de ölenin ana ve babasına ölüm geliri bağlanmaktadır (Tuncay ve Ekmekçi, 2017, s. 417).

Bu açıklamalar çerçevesinde, ölen sigortalının hak sahiplerine ölüm aylığının bağlanabilmesi için, ölen sigortalının sigortalılık süresi veya prim gün sayısı açısından belli sigortalılık şartlarını taşıması beklenmektedir. Ancak, ölüm gelirinin bağlanabilmesi için ölenin bu şartları taşıması (tarım işi yapan sigortalılar hariç) gerekmemektedir (Keleş, 2015, s. 215). Ayrıca, sigortalının iş kazası sonucu ölmesi nedeniyle iş kazası ve meslek hastalığı sigortasından gelir alma hakkı olan hak sahiplerinin ölüm sigortasından da aylığa hak kazanması mümkün bulunmaktadır (Güzel vd., 2020, ss. 362-363). Bu durumda çalışanın ölümü halinde hak sahiplerine hem ölüm gelirinin hem de ölüm 
aylığının bağlanması gündeme geldiği takdirde 5510 sayılı Kanunun 54. maddesinin uygulanması isabetli olacaktır. Buna göre, ölüm geliri ile ölüm aylığından hangisi yüksek ise onun tamamı, az olanın ise yarısı ödenir. Ancak, ölüm geliri ile ölüm aylığının eşit olması halinde, ölüm gelirinin tamamı ölüm aylığının ise yarısının ödenmesi gerekmektedir.

\section{Evlenme Ödeneği ve Cenaze Ödeneği}

5510 sayılı Kanunun 37. maddesinde belli koşulların varlığı halinde kız çocuklarına evlenme ödeneğinin verileceği ve ölenin hak sahiplerine cenaze ödeneğinin verileceği de düzenlenmiştir.

5510 say1lı Kanunun 37. maddesine göre, evlenmeleri nedeniyle, gelir veya aylıklarının kesilmesi gereken kız çocuklarına evlenmeleri ve talepte bulunmaları halinde almakta oldukları aylık veya gelirlerinin iki yıllık tutarı bir defaya mahsus olmak üzere evlenme ödeneği olarak peşin ödenir. Evlenme ödeneği alan hak sahibinin aylığının kesildiği tarihten itibaren iki yıl içerisinde yeniden hak sahibi olması halinde, iki yıllık sürenin sonuna kadar gelir veya aylık bağlanmayacaktır. Ancak bu durumda olanların 60. maddenin birinci fikrasının (f) bendi kapsamında genel sağlık sigortalısı sayılacağı hususu yine 5754 sayılı kanunla yapılan değişikliklerden biridir.

Evlenme ödeneği verilmesi halinde, diğer hak sahiplerinin aylık veya gelirleri evlenme ödeneği verilen sürenin bitimini takip eden ödeme döneminden itibaren 34 üncü maddeye göre yeniden belirlenir.

İş kazası veya meslek hastalığg sonucu veya sürekli iş göremezlik geliri, malûllük, vazife malûllügü veya yaşl1lık aylığı almakta iken veya kendisi için en az 360 gün malûllük, yaşlılık ve ölüm sigortası primi bildirilmiş olup da ölen sigortalının hak sahiplerine Kurum Yönetim Kurulunca belirlenip Bakan tarafindan onaylanan tarife üzerinden cenaze ödeneği ödenir. Cenaze ödeneği, sırasıyla sigortalının eşine, yoksa çocuklarına, o da yoksa ana babasına, o da yoksa kardeşlerine verilir.

Cenaze ödeneğinin üçüncü fikrada sayılanlara ödenememesi ve sigortalının cenazesinin gerçek veya tüzel kişiler tarafından kaldırılması durumunda, üçüncü fikrada belirtilen tutarı geçmemek üzere belgelere dayanan masraflar, masrafı yapan gerçek veya tüzel kişilere ödenir. 
4 üncü maddenin birinci fikrasının (c) bendi kapsamında sigortalı sayılanlardan ölenlerin hak sahiplerine kendi kurumları tarafından ilgili mevzuat gereği ölüm yardımı hariç cenaze gideri, cenaze nakil gideri ödeneği veya bu mahiyette bir ödemenin yapılması halinde, Kurum tarafından cenaze ödeneği ödenmez.”

Evlenme ödeneği bir defaya mahsus olarak verilmektedir. Bu nedenle evlenme ödeneğini bir kez almış olan kız çocuğu, daha sonra boşanmış veya dul kalmış ise bu kişiye tekrar ölüm aylığı veya ölüm geliri bağlanacaktır (Tuncay ve Ekmekçi, 2017, ss. 416-417). Bu nedenle bu kız çocuğunda daha sonraki evliliklerinde evlenme ödeneğinin verilmesi söz konusu olmayacaktır (Mülayim, 2011, ss. 106-107 ). Ayrıca, cenaze ödeneği de iş kazası veya meslek hastalığı sonucu yaşamını yitiren sigortalının hak sahiplerine ödenmektedir. $\mathrm{Bu}$ anlamda sigortalının eşi veya çocuklarının ölmesi halinde sigortalıya bu başlık altında bir ödemenin yapılması mümkün bulunmamaktadır (Mutlay, 2014, ss. 277-278).

Bu doğrultuda, iş kazasına uğrayan sigortalı ve sigortalının ölümü halinde sigortalıya ve hak sahiplerine birtakım ödememeler yapılmakla birlikte, gelir bağlanması da mümkün bulunmaktadır. Ancak, bu ödemelerin yapılması ve bu gelirlerin bağlanması için birtakım şartların bulunması gerekmektedir (Civan, 2015, s. 1017).

\section{Sonuç ve Değerlendirme}

Sigortalıya bedenen ve ruhen zarar veren ve beklenmedik bir anda yaşanan olayların iş kazası olarak kabul edilmesi mümkün bulunmaktadır. Bu nedenle iş kazası sonucu iş kazasına uğrayan sigortalıda birtakım bedeni ve ruhi bozukluklar gün yüzüne çıkmaktadır. Ayrıca, iş kazasına uğrayan sigortalı bedenen ve ruhen zarar görmekle birlikte, sigortalı birtakım maddi zorluklar içine de girmektedir. Zira iş kazasına uğrayan sigortalı bir taraftan bir gelir kaybına uğramakla birlikte, diğer taraftan işini kaybetme tehlikesi de yaşamaktadır. Bu nedenle iş kazasına uğrayan sigortalı hukuki açıdan korunmaya muhtaçtır. Bunun içindir ki, iş kazasına uğrayan sigortalının hukuken himaye altına alınması oldukça önemlidir. Ayrıca, iş kazasına uğrayan sigortalında bir işgücü kaybı da ortaya çıkmaktadır. Bunun yanında iş kazasına uğrayan sigortalının iş kazası sonucu hayatını kaybetmesi de mümkün bulunmaktadır. Bu durumda da ölen sigortalının eşi, çocukları ve ana babası birtakım mağduriyetler yaşamaktadır. Dolayısıyla bu kişilerin de hukuken korunması gerekmektedir. Zira bu kişiler ölen kişinin eşi, 
çocukları veyahut ana ve babasıdır ki, bu nedenle bu kişiler ölen sigortalının hak sahipleri olarak anılan kişilerdir.

$\mathrm{Bu}$ doğrultuda, 5510 sayılı Kanun iş kazasına uğrayan sigortalıya çeşitli haklar tanımıştır. Ayrıca, 5510 sayılı Kanun iş kazasına uğrayan sigortalının ölümü halinde hak sahiplerine de birtakım haklar tanımıştır. Buna göre, 5510 sayılı Kanunun 16. maddesinde iş kazasına uğrayan sigortalının ve sigortalının ölümü halinde hak sahiplerinin ne gibi haklarının bulunduğu hükme bağlamıştır. $\mathrm{Bu}$ bağlamda, iş kazasına uğrayan sigortalının tedavi süresi boyunca geçici iş göremezlik ödeneği alabileceği, ayrıca iş kazasına uğrayan sigortalının iş göremezlik oranının \%10'un üzerinde olması halinde ve bu durumun sağlık kurulu raporuyla tespit edilmesi halinde sigortalının sürekli iş göremezlik ödeneği almaya hak kazanacağı hükme bağlamıştır. Bu şekilde iş kazasına uğrayan sigortalının tedavi görüp iyileşene kadar geçici iş göremezlik ödeneği alabileceği ve iş kazası sonucu en az \%10 iş göremez hale gelen sigortalının iş göremezlik oranına göre bir sürekli iş göremezlik ödeneği alması gerektiği düzenlenmiştir. Böylece iş kazasına uğrayan sigortalıya hukuki bir koruma sağlanmak istenmiştir. Zira sosyal güvenliğin temel amaçlarından biri de bireylerin ekonomik risklere karşı korunmasını sağlamak ve bireylerin bir başkasına muhtaç hale gelmemesini temin etmektir. Sigortalıya verilecek geçici iş göremezlik ödeneği veya sigortalıya bağlanan sürekli iş göremezlik geliri ile sigortalının iş kazası nedeniyle uğramış olduğu maddi kayıpların ortadan kaldırılması veyahut asgari bir seviyeye indirilmesi amaçlanmıştır. İş kazasına uğrayan sigortalıya verilen geçici iş göremezlik ödeneği ve sigortalıya bağlanan sürekli iş göremezlik geliri sigortalıya sağlanan parasal yardımlar olmakla birlikte, iş kazasına uğrayan sigortalıya sağlık yardımları da yapılmaktadır. Ancak şu husus belirtilmelidir ki, sigortalıya yapılan sağlık yardımları genel sağlık sigortası kapsamında yapılan yardımlar olmakla birlikte, iş kazasına uğrayan sigortalıya geçici iş göremezlik ödeneği veya sürekli iş göremezlik geliri şeklinde yapılan parasal yardımlar ise, bir kısa vadeli sigorta kolu olan iş kazası ve meslek hastalığı sigortası kapsamında yapılan yardımlardır.

İş kazasına uğrayan sigortalı iş göremez hale gelebileceği gibi sigortalının iş kazası nedeniyle hayatını kaybetmesi de mümkün bulunmaktadır. Bu durumda hak sahibi olan ölen sigortalının eşi, çocukları ana ve babasının hukuki durumunun ne olacağı ve bu kişilerin ne gibi haklarının olduğu sorusu akla gelmektedir. Bu perspektiften bakıldığında, 5510 sayılı Kanunun 16. maddesine 
göre, hak sahiplerinin ölüm geliri, ölüm aylığı, cenaze ödeneği ve evlenme ödeneği alması mümkün bulunmaktadır. Bu bağlamda, ölen sigortalının hak sahiplerine ölüm geliri verilebileceği gibi, ölüm aylığının bağlanması da mümkün bulunmaktadır. Ölüm geliri kısa vadeli sigorta kolu olmakla birlikte, ölüm aylığı uzun vadeli bir sigorta koludur. Bu nedenle hak sahiplerine ölüm gelirinin bağlanması için aranan şartlar ile ölüm aylığının bağlanması için aranan şartlar farklılık göstermektedir. Ölüm gelirinin kısa vadeli sigorta kolu kapsamında hak sahiplerine yapılan bir ödeme kalemi olması nedeniyle hak sahiplerine ölüm gelirinin verilmesi için ölen sigortalının sigortalılık süresi veya sigorta primi açısından belli kriterleri yerine getirmesi koşulu aranmamaktadır. Ancak, ölüm aylığı uzun vadeli bir sigorta kolu olan ölüm sigortası kapsamında bağlandığı için ölen sigortalının sigortalılık süresi ve sigorta primi açısından belli şartları yerine getirmiş olması gerekmektedir. Ayrıca, 5510 sayılı Kanunda ölüm geliri ile ölüm sigortasının birlikte hak sahiplerine verilmesinin gündeme geldiği hallerde hangi esasların uygulanması gerektiği de hükme bağlanmıştır. Buna ek olarak, ölen sigortalının hak sahiplerinin hangi şartlar altında cenaze ödeneği ve evlenme ödeneğine hak kazanabileceği özel olarak düzenlenmiştir. Bu açıklamalardan hareketle iş kazasına uğrayan sigortalının ve sigortalının ölümü halinde hak sahiplerinin birtakım hakları bulunmaktadır. Bu şekilde 5510 sayılı Kanun iş kazasına uğrayan sigortalı ve hak sahiplerine hukuki bir koruma getirmiştir.

Sonuç olarak, iş kazası neticesinde gerek iş kazasına uğrayan sigortalı gerek sigortalının ölümü halinde hak sahipleri birtakım mağduriyetler yaşamaktadır. Bunun içindir ki, 5510 sayılı Kanun iş kazasına uğrayan sigortalılara çeşitli haklar tanımıştır. Ayrıca, 5510 sayılı Kanun iş kazasına uğrayan sigortalının ölümü halinde hak sahiplerinin hukuki durumunu da göz ardı etmemiş ve hak sahiplerine de çeşitli haklar tanımıştır. Bu şekilde iş kazasına uğrayan sigortalının ve sigortalının ölümü halinde hak sahiplerinin içinde bulunduğu zor durumun bir nebze olsun hafifletilmesi amaçlanmıştır.

Hakem Değerlendirmesi: Dış bağımsız.

Çıkar Çatıșması: Yazar çıkar çatışması bildirmemiștir.

Finansal Destek: Yazar bu çalışma için finansal destek almadığını beyan etmiştir.

Peer-review: Externally peer-reviewed.

Conflict of Interest: The author has no conflict of interest to declare.

Grant Support: The author declared that this study has received no financial support. 


\section{Kaynakça/References}

Akdeniz A. L. (2014). İşverenin İş Kazası ve Meslek Hastalıklarından Doğan Zararlardan Sorumluluğunun Niteliği, $\dot{I} \ddot{H} H F M, 2,3-30$.

Alper Y, (2015). Türk Sosyal Güvenlik Sistemi ve Sosyal Sigortalar Hukuku, Bursa: Dora Yayınc1lik.

Alper Y., Kılkış İ., (2017), İş ve Sosyal Güvenlik Hukuku, Bursa: Dora Yayıncılık.

Balcı M. (2019). Ölüm Gelir ve Aylıklar, Ankara: Yetkin Yayınları.

Baycık G. (2013). Çalışanların İş Sağlığı ve Güvenliğine İlişkin Haklarında Yeni Düzenlemeler, Ankara Barosu Dergisi, 3, 103-170.

Baybora Dilek B. (2013), Türkiye'de İş Kazaları ve Meslek Hastalıkları ve Sosyal Güvenlik Sistemi İçindeki Yeri, International Conference on Eurasıan Economies.

Civan O. E. (2015). İş Kazası veya Meslek Hastalığından Doğan Rücu Davalarında Sosyal Güvenlik Kurumu Karşısında Sorumluluğun Kapsamı ve Müteselsil Sorumluluk, Ankara Üniversitesi Hukuk Fakültesi Dergisi, 4, 1015-1070.

Çenberci M. (1995). Sosyal Sigortalar Kanunu Şerhi, Ankara.

Demiral E. G. (2017), İ̧̧ Kazaları, Ankara: Seçkin Yayıncılık.

Elma R. (2019). Örnekler ve Uygulamalarla Sosyal Güvenlik Hukuku, Ankara: Seçkin Yayıncilık.

Emirhan F. (2017). İşverenin İş Kazasından ve Meslek Hastaliğından Dŏgan Sorumluluğunun Hukuki Niteliği, İstanbul: On İki Levha Yayıncılık.

Görgöz O. (2019). İşverenin İş Kazası Sonrası Tazminat ve Rücu Ödemeleri, Ankara: Seçkin Yayıncılık.

Göktaş M. (2012). İş Kazası Ve Meslek Hastalığı Sonucu Ölen Sigortalıların Hak Sahiplerine Ölüm Geliri Ödenmesi, Mali Çözüm Dergisi, 201-210.

Günay C. İ. (2020). İş ve Sosyal Güvenlik Hukuku, Ankara: Yetkin Yayıncılık.

Güneren A. (2020). İş Kazası veya Meslek Hastalı̆̆ı̆ndan Kaynaklanan Maddi ve Manevi Tazminat Davaları, Ankara: Seçkin Yayıncılık.

Gökalp Civan A. (2020). Sosyal Güvenlik Hukukunda Ölüm Sigortası, Ankara Üniversitesi, Özel Hukuk Anabilim Dalı, Yüksek Lisans Tezi, Ankara.

Güzel A., Okur A. R. ve Caniklioğlu N. (2020). Sosyal Güvenlik Hukuku, İstanbul: Beta Yayıncilık.

Karakaş İ. (2019). Tüm İşyerleri İçin Uygulamalı Sosyal Güvenlik El Kitabı, Ankara: Gözlem Yayıncılık.

Kaynak Z. (2018). Sosyal Sigorta ve Uygulamasl, Ankara: Adalet Yayınevi.

Keleş S. M. (2015). Ölüm Geliri Nasıl Hesaplanır ve Kimlere Ödenir, iSMMmO Mali Çözüm Dergisi, 134, 215-219.

Kılıçoğlu A. M. (2020). Borçlar Hukuku Genel Hükümler, Ankara: Turhan Yayıncılık. 
Mülayim O. (2011). Türk Sosyal Güvenlik Sisteminde Kısa Vadeli Sigorta Kolları Uygulamaları, Gazi Üniversitesi, Çalışma Ekonomisi ve Endüstri İlişkileri Anabilim Dalı, Yüksek Lisans Tezi, Ankara.

Mutlay F. B. (2014). Sosyal Sigorta Yardımlarına Hak Kazanma Koşulları ve Eşitlik Ilkesi, İstanbul: Beta Yayınc1lık.

Narter S. (2015). Meslek Hastalığında Sorumluluklar ve Sigortasız Çalışanın Meslek Hastalığına Tutulması, Karatahta / İs Yazlları Dergisi, 2, 19-43.

Narter S. (2017). İş Kazası ve Meslek Hastalığında Hukuki ve Cezai Sorumluluk, Ankara: Adalet Yayınevi.

Oğuz Ö. (2018). İş Kazası ve Meslek Hastalığında Sigortalıya Sağlanan Yardımlar, HAKIŞ Uluslararası Emek ve Toplum Dergisi, 18, 317-332.

Olgaç C., Tuncay S. ve Bulut M. (2011). Kısa Vadeli Sigorta Kollarl Uygulamalarl, Ankara: Bilge Yayıncılık.

Özdemir C. S. (2008). Soru ve Cevaplarla Sosyal Güvenlik Reformu Uygulama Rehberi, Ankara: Adalet Yayınevi.

Pehliban M, (2020), Türk Sosyal Güvenlik Sisteminde (5510 Sayılı Kanun) Kısa Vadeli Sigorta Kollarından Sağlanan Yardımlar, Hukuk Yayınları.

Sözer A. N. (2019). Türk Sosyal Sigortalar Hukuku, İstanbul: Beta Yayınc1lık.

Sümer H. H. (2020). İş Sağlı̆̆l ve Güvenliği Hukuku, Ankara: Seçkin Yayıncılık.

Topaloğlu S. ve Çınkı F. (2014). İş Kazası ve Meslek Hastalı̆̆ı Haklar Yaptırımlar Yükümlülükler Tazminat ve Ceza Sorumluluklarl, Ankara.

Tuncay A. C. ve Ekmekçi Ö. (2017), Sosyal Güvenlik Hukuku Dersleri, İstanbul: Beta Yayıncilik.

Yavuz N. (2015). Türk Borçlar Kanunu Şerhi Ankara: Adalet Yayınevi.

Yazıcı A. S. ve Çetin E (2018), İş Kazası ve Meslek Hastalığı Sigortasında Sürekli İş Göremezlik Geliri, Karatahta/İs Yazıları Dergisi, 11, 33-67.

Yılmaz A. (2017). Sosyal Güvenlik Hukukunda İş Kazası Kavramı: Kıta Avrupası ve Anglosakson Hukuk Sistemlerinden Birer Örnek İle Türk Hukuku Karşılaştırması, Sosyal Güvenlik Dergisi, 2, 107-127.

Yorulmaz Ç. (2010). Ölüm Sigortas1, Ankara Barosu Dergisi, 3, 289-309.

https://www.emsal.yargitay.gov.tr.

https://www.hukukmedeniyeti.org.

https://www.ismahkemesi.com.

https://www.kazanci.com.

https://www.legalbank.net. 